\title{
Post-medieval Pottery in Mazovia and Podlachia (16th-18th Century) - a Preliminary Report
}

\author{
Maciej Trzeciecki ${ }^{a}$
}

\begin{abstract}
The text is dedicated to the question of traditions and innovations in post-medieval pottery manufactured and used in the territory of today's Mazovia and Podlachia in Poland. It focuses on the distribution of waregroups in the assemblages from selected sites dated to the mid-16th - late 18th centuries. The list includes both capital cities in the province (Warsaw, Płock) and local towns (Ciechanów, Płońsk, Przasnysz), as well as royal and aristocratic residences, gentry manors and villages. Among the most characteristic features worthy of note are the long lasting of early medieval manufacturing traditions, the widespreaduse of greyware, the relatively small proportion of whiteware and glazed vessels, as well as the sporadic (excluding Warsaw) occurrence of fineware (porcelain, faience). The analysis points to the specificity of Mazovian pottery in 16th-18th centuries, in relation to both other Polish lands and our notions on trends in pottery manufacture and use in the post-medieval period.
\end{abstract}

KEY-WORDS: pottery, post-medieval period, Mazovia, Podlachia, ware groups

The post-medieval period can be considered as transition between the Middle Ages and modernity, a process spreading over several centuries. The clash between the "old" and "new", the confrontation of traditional normative discourses with the dynamic, sometimes violent, emergence of new political, economic, and socio-cultural relations is among the key features of the years between the discovery of America and the French Revolution. The extensive mobility of both people and commodities, triggered by the great geographical opening, fostered the creation of global economic networks, the emancipation of new social classes and the transfer of new or exotic cultural models (see, e.g., McCants 2007; Gerritsen 20I6, with further literature). All these processes are reflected in the material relics of social life, including ceramic vessels.

Several factors deserve particular attention when considering the tension between traditions and innovations in pottery manufacture and use. Technological progress, 
$32 \mid$ Maciej Trzeciecki

embodied by the European discovery of porcelain recipes, is among the pivotal ones. The gradual decline of medieval institutions that regulated both pottery manufacture and distribution, namely, the guild system, is also of significant importance. One should pay particular attention to the increasing mobility that stemmed from the colonization of newly discovered lands, urbanization, and development of long-distance trade. This triggered the emergence of new patterns of social life, including modes of consumption, compatible with the ambitions and needs of new privileged social classes. The aforementioned questions, particularly changes in consumption patterns and table culture, are present in academic discourse, although the researchers' interest has focussed mainly on the core areas of the post-medieval Western world (see, e.g., Deetz 1977; Cassidy-Geiger 2007; Majewski and Schiffer 2009; Berg et al., 20I5, with further literature).Thus, an attempt to look at the socio-cultural transformations on the European peripheries through the lens of pottery finds appears to have significant cognitive potential.

The following text focuses on the "old" and "new" phenomena in post-medieval pottery production and use in the territory of today's Mazovia and Podlachia. The choice is not accidental - both territories had a peripheral character at that time, with the weakest impact of urbanization. We should, therefore, expect a relatively long duration of traditional ways of manufacture, along with the slow dissemination of innovations. It must be, however, stressed that since the mid-I6th century, Mazovia and Podlachia were actively involved in the large-scale grain trade, essential for the economic prosperity of the entire country. Mazovia was also the location of the capital of the Polish-Lithuanian Commonwealth, Warsaw. The role of this city as the capital, together with the participation of Mazovian towns in the grain trade could have created favourable conditions for the adaptation and dissemination of new technologies and stylistic patterns.

For a long time, not much interest was taken by archaeologists of post-medieval pottery, and Mazovia has been no exception here, although it should be emphasized that the ceramic assemblages from the excavations of the Old Town and Royal Castle in Warsaw were among the first Polish publications of finds from the post-medieval period (see, e.g., Świechowska and Dukwicz 1955; Gierlach 1966; Janiszowski 1966). Excavations conducted over the last 30 years, related mainly to developments on both a supra-regional (the laying of the Yamal gas pipeline, the construction of motorways) and local scale (revitalization of town centres), have provided numerous and diverse groups of finds, regrettably, still largely unpublished (see: Bieńkowska and Kiziukiewicz 2006; Bis and Bis 20I2; Pela 2013; Lis 20I7, for further literature). Nevertheless, the data contained in publications and research reports allow us an overview of the ceramic material recovered from a selection of sites dated between the 16th and I8th centuries. The assemblages of potsherds obtained there provide the basis for a preliminary evaluation of post-medieval pottery in Mazovia and Podlachia.

Due to limitations of space, this paper will concentrate on the issue of the differing proportions of ware groups in chosen assemblages of the period discussed. Of key 
importance is the question of the mutual relations between pottery groups recognized as "traditional" (brownware, greyware) and those that were "progressive" (glazed ware, whiteware, fineware). The majority of the assemblages selected have been the subject of studies conducted personally by the author, with the application of a uniform set of statistical methods introduced by Jerzy Kruppé (1967; see also Trzeciecki 20I6: 37-46, for further literature). Other assemblages have been included that had been analyzed with the use of the aforementioned (or comparative) set of methods and published in a form allowing the raw data to be used here. The selection focused on providing the broadest possible representation of the basic site groups, namely, towns, palaces of the aristocracy, manors of the gentry, and villages (Fig. I; Table I). It is worth noting that all of the finds presented here have been acquired in the course of rescue excavations.

Data on pottery in use in Mazovian towns are provided by the assemblages from the excavations conducted in Warsaw as well as in other Mazovian towns: Płock, Ciechanów, Płońsk, Przasnysz, Bielsk Podlaski. It should be stressed that in the case of the majority of the towns discussed here, the selected assemblages provide only partial information, concerning specific places within the urban space. Only in the case of Płock, do we have at our disposal data that create the basis for studying changes in the manufacture and use of pottery in areas situated across the whole municipal complex. Vessels from royal and aristocratic seats are represented by assemblages from eighteenth-century Warsaw residences: the Branicki, Jabłonowski and Witosławski palaces, along with the pottery from the royal castle in Tykocin, the residence of the Sapieha family in Dubno, and the Branicki Palace in Białystok. Assemblages from manors of the gentry derive from Gaj Nowy, Niegów, and from a type of settlement structure specific to post-medieval Mazovia and Podlachia, namely, petty-gentry villages (Brulino-Koski, Zambrzyce Stare). There has been very little archaeological investigation of post-medieval peasant villages, particularly when compared to the amount of excavations in towns. Therefore, only assemblages from three villages located in the vicinity of Warsaw (Komorowo, Rusiec, and Strzeniówka) have been included, along with the pottery assemblage from the peasant village of Leonowicze in Podlachia.

Among the atavistic features of Mazovian pottery-making, worthy of particular attention are: the long duration of early medieval manufacture traditions, such as tempering clay with crushed stones, the use of a coiling technique, and the firing of the products in an uncontrolled oxidizing atmosphere. So-called "traditional" vessels occur in the assemblages from towns. In early sixteenth-century Płock, the quantity reaches $14.6 \%$, to drop to almost $2 \%$ in the early 17 th century. Interestingly, in Płock they occurred mainly in the castle and estates belonging to the nobility and clergymen that lived in the town but they were not involved in its social and economic structures (Trzeciecki 2016: $198 \mathrm{ff}$ ). The relatively low quantities of traditional vessels from both Warsaw (Castle Sq., up to I\%) and small towns that were founded around I400 - Ciechanów (Market Sq., 2.4\%), Płońsk (Zduńska St., 0.7\%), and Przasnysz 


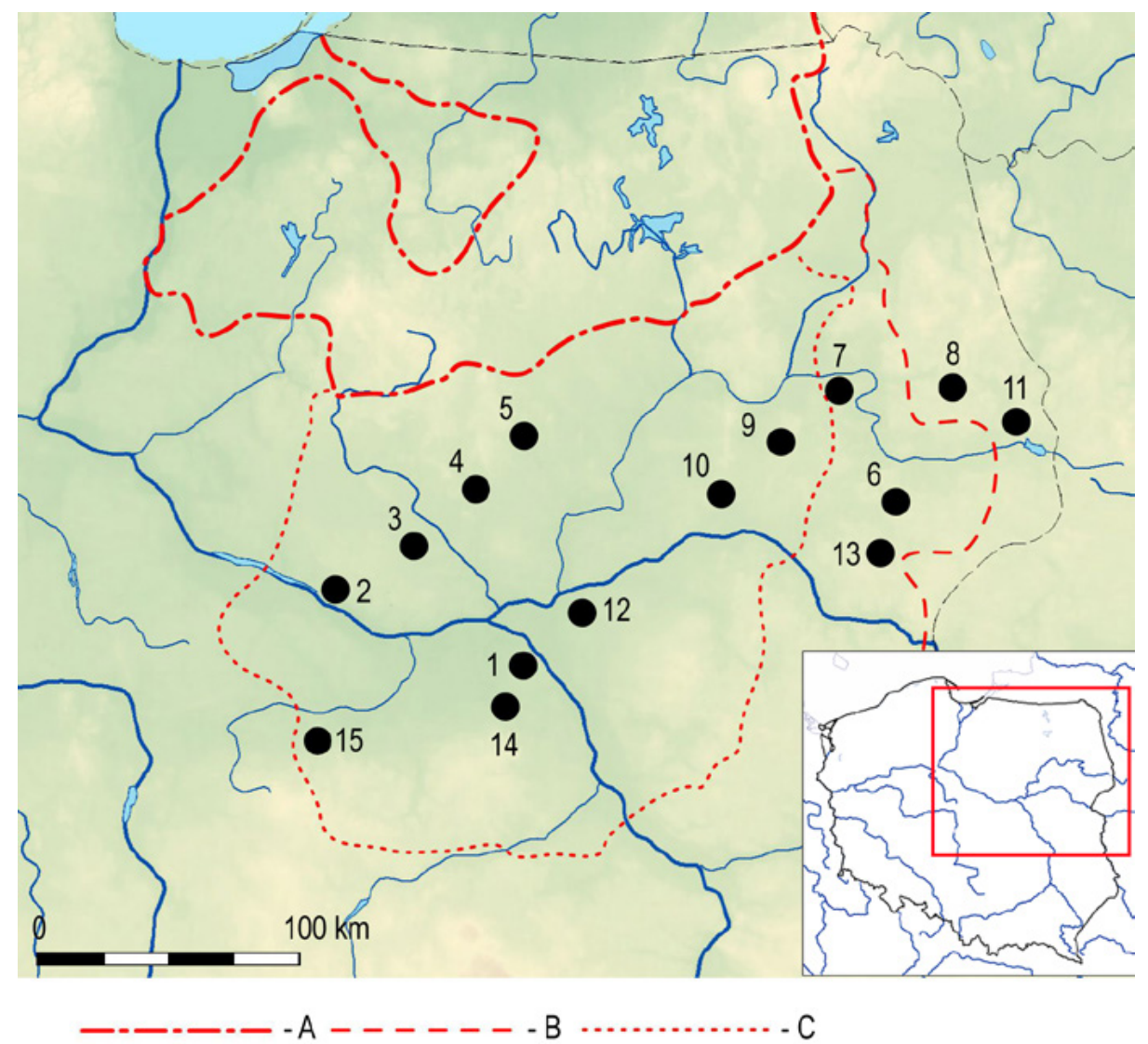

Fig. 1. Location of the archaeological sites mentioned in the text. A - frontier of the Polish-Lithuanian Commonwealth in the 16th-18th centuries, B - internal frontier between Poland and the Grand Duchy of Lithuania after 1569, C - Duchy of Mazovia in the 15th century. 1 - Warsaw, 2 - Płock, 3 - Płońsk,

4 - Ciechanów, 5 - Przasnysz, 6 - Bielsk Podlaski, 7 - Tykocin, 8 - Białystok, 9 - Zambrzyce Stare, 10 - Brulino-Koski, 11 - Leonowicze, 12 - Niegów, 13 - Dubno, 14 - Komorów, Rusiec, and Strzeniówka (villages in the vicinity of Warsaw), 15 - Gaj Nowy. The numbers correspond with Table 1.

(Czeladnicza St., 0.5\%) point to the links between this group of ceramics and the rural hinterland. Traditional vessels finally disappeared from the Mazovian towns by the mid-I7th century.

Early medieval pottery-making traditions lasted much longer in villages and manors. Clear regional differences should be stressed here - the quantity of traditional vessels grows significantly in the eastern part of the discussed territory, in the least 
Table. 1. List of the sites mentioned in the text with chronology and literature references. Site numbers correspond with the map in Fig. 1.

\begin{tabular}{|c|c|c|c|c|}
\hline & Site & Settlement type & Chronology & Literature \\
\hline 1a & Warsaw, Castle Sq. & town & 16th -18 th $\mathrm{c}$ & Trzeciecki 2017 \\
\hline $1 b$ & Warsaw, Browarna St. & town & 18th c. & $\begin{array}{l}\text { Trzeciecki and Rudnicki } \\
2021\end{array}$ \\
\hline 1c & $\begin{array}{l}\text { Warsaw, Branicki } \\
\text { palace }\end{array}$ & $\begin{array}{l}\text { aristocracy } \\
\text { residence }\end{array}$ & $\begin{array}{l}\text { mid-17th - mid- } \\
18 \text { th c. }\end{array}$ & Trzeciecki 2020a \\
\hline $1 d$ & $\begin{array}{l}\text { Warsaw, Jabłonowski } \\
\text { palace }\end{array}$ & $\begin{array}{l}\text { aristocracy } \\
\text { residence }\end{array}$ & 17 th -19 th $\mathrm{c}$ & Starski 2013 \\
\hline 1e & $\begin{array}{l}\text { Warsaw, Witosławski } \\
\text { palace }\end{array}$ & $\begin{array}{l}\text { aristocracy } \\
\text { residence }\end{array}$ & 18th c. & $\begin{array}{l}\text { Smoliński and Trzeciecki } \\
2020\end{array}$ \\
\hline 2 & Płock & town & 16th -19 th $\mathrm{c}$ & Trzeciecki 2016 \\
\hline 3 & Płońsk, Zduńska St. & town & 16 th -17 th $c$ & Smoliński et al., 2010 \\
\hline 4 & Ciechanów, Market Sq. & town & 16th - early 18 th c. & Trzeciecki and Affelski 2016 \\
\hline 5 & $\begin{array}{l}\text { Przasnysz, Czeladnicza } \\
\text { St. }\end{array}$ & town & 16 th -18 th c. & $\begin{array}{l}\text { Smoliński and Trzeciecki } \\
2010\end{array}$ \\
\hline 6 & Bielsk Podlaski & town & 16th -18 th $\mathrm{c}$ & Pawlata 2015 \\
\hline 7 & Tykocin & royal castle & 16th - early 17 th c. & Auch and Trzeciecki 2015 \\
\hline 8 & Białystok & $\begin{array}{l}\text { aristocracy } \\
\text { residence }\end{array}$ & 18th c. & Pawlata 2013 \\
\hline 9 & Zambrzyce Stare & $\begin{array}{l}\text { petty-gentry } \\
\text { village }\end{array}$ & 16th - early 17 th c. & Trzeciecki and Affelski 2017 \\
\hline 10 & Brulino-Koski & $\begin{array}{l}\text { petty-gentry } \\
\text { village }\end{array}$ & 16th c. & Musianowicz 1975 \\
\hline 11 & Leonowicze & peasant village & $\begin{array}{l}\text { mid-16th - early } \\
18 \text { th c. }\end{array}$ & Gołembnik et al., 2018 \\
\hline 12 & Niegów & gentry manor & mid-17th -18 th c. & Trzeciecki 2017b \\
\hline 13 & Dubno & $\begin{array}{l}\text { aristocracy } \\
\text { residence }\end{array}$ & 17 th -18 th $\mathrm{c}$ & Garas and Karwowska 2013 \\
\hline $14 \mathrm{a}$ & Komorów & peasant village & 16th -18 th $\mathrm{c}$ & Morysiński 2015 \\
\hline $14 b$ & Rusiec & peasant village & 16th -18 th c. & Morysiński 2015 \\
\hline $14 \mathrm{c}$ & Strzeniówka & peasant village & 16th -18 th $c$ & Morysiński 2015 \\
\hline 15 & Gaj Nowy & gentry manor & 16th -17 th $c$. & Świątkiewicz 1992 \\
\hline
\end{tabular}


urbanized areas of the former medieval Polish-Ruthenian borderland. In the collections of pottery from sixteenth-century villages and manors in left-bank Mazovia, however, traditional vessels constitute a maximum of a few percent and disappear before the end of the century (Świątkiewicz 1992: 279-280; Morysiński 2005: 384-390, tables 2-9). Assemblages from eastern Mazovia provide entirely different proportions. The villages of Brulino-Koski and Zambrzyce Stare, established in the I6th century and inhabited by petty gentry, with the proportion of traditional vessels of $70-80 \%$, can serve as a good example here (Musianowicz 1975: 150-15I, table I; Trzeciecki and Affelski 2017: I7I-172). The quantities of traditional ware reach $44 \%$ in the sixteenth-century assemblage of kitchenware from the royal castle in Tykocin (Auch and Trzeciecki 2015: 19I-192). The assemblage of vessels from Leonowicze, a peasant village in Podlachia established in the mid-I6th century and abandoned in the early I8th century, included about $90 \%$ of the traditional ware (Gołembnik et al., 20I8: 335-336). Early medieval pottery-making techniques lasted in eastern Mazovia and Podlachia up to the early I8th century, as evidenced by the single finds of traditional vessels from the excavations held in the gentry manor in Niegów, and palaces of the aristocracy in Dubno and Białystok (Garas and Karwowska 20I3: 228; Pawlata 20I3: I3I-I32; Trzeciecki 20I7b: I7I, I85). Interesting regional differences are reflected also in the repertoire of forms - traditional vessels from western and northern Mazovia imitate greyware pots (Fig. 2:I-9), while in eastern Mazovia and Podlachia the influence of pottery styles of Black Rus', unchanged since the I2th century, predominate (Fig. 2:IO-I5; Auch and Trzeciecki 20I5: 194-195).

Since the publication of the first - and so far the only - attempt to synthesize the transformations of post-medieval pottery in Poland (Gajewska 1993), a high percentage of vessels fired in a reducing atmosphere has been taken as an indicator of the impact of medieval traditions (e.g., Kajzer 1994; 1996: 216-218; Morysiński 2005: 412-4I3; Marcinkowski 2009: 2II-2I2). In the case of Mazovia, however, the dissemination of greyware was of a different nature. This ware group appeared there relatively late, along with location of Płock and Warsaw in I300. Up to the late I4th century, the manufacture and distribution of greywares was limited mainly to the aforementioned towns. The wider dissemination of greyware vessels was related to the urbanization of western and northern Mazovia that started around I400. Up to the end of the I5th century, they constituted almost 100\% of the pottery assemblages from towns. The percentages of greyware vessels began to decrease in the i6th century. The decline is most visible in the case of Warsaw (Castle Sq.) - from over 90\% at the end of the 15 th century to $17 \%$ in the late I6th century, and only $3.5 \%$ in the mid-18th century. The quantity of greyware in the assemblages from smaller towns, dated to the second half of the i6th century, is significantly higher - up to 60\% in Płock, Ciechanów (Market Sq.), and Przasnysz (Czeladnicza St.). It reaches more than $80 \%$ in the collections of pottery from Płońsk (Zduńska St.) and Bielsk Podlaski. The percentage of greyware slowly decreased during the I8th century, below 22.5\% in Płock and 38\% in Przasnysz 

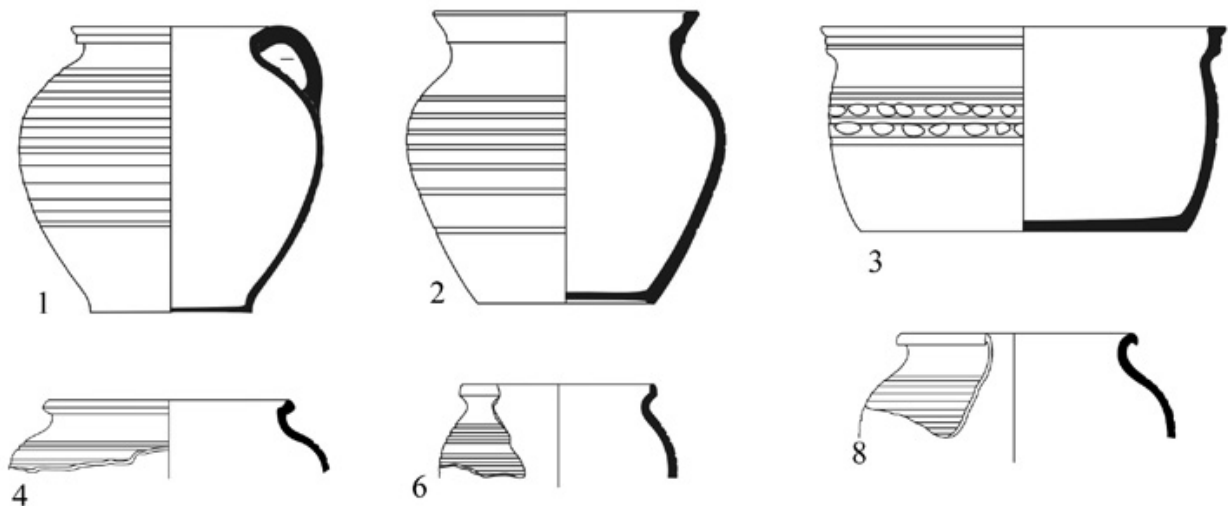

4
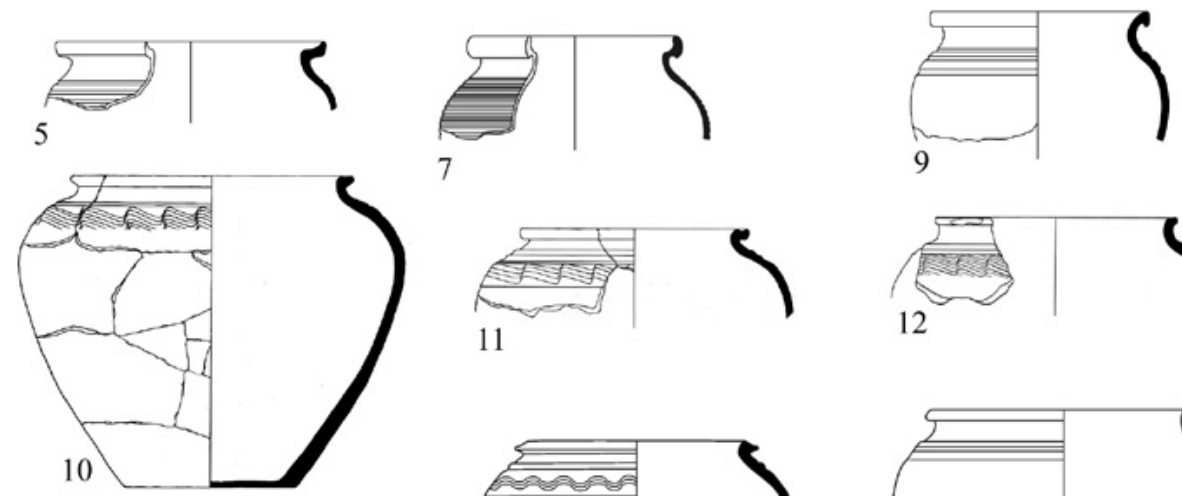

11

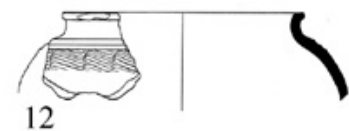

12

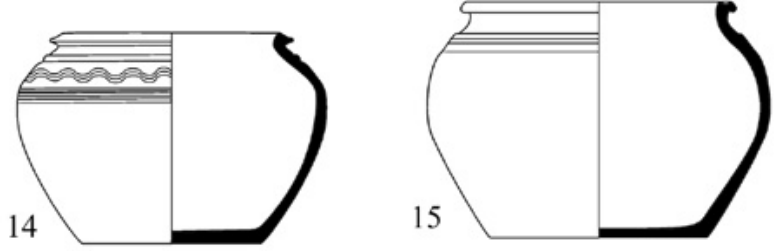

13
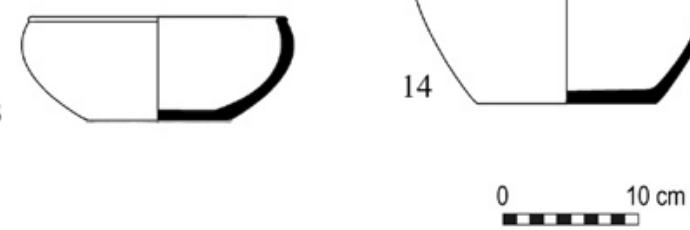

Fig. 2. Selection of traditional vessels from the second half of the 16th century to the mid-17th century: Płock (1-3), Warsaw, Castle Sq. (4, 5), Niegów (6, 7), Zambrzyce Stare (8, 9), Tykocin (10-12), Leonowicze (13-15). 1-9, 13-15 drawn by M. Trzeciecki, 10-12 after Auch, Trzeciecki 2015.

(Czeladnicza St.). It should be however noted here that single greyware vessels are still present in the nineteenth-century pottery assemblages from Mazovian towns (Trzeciecki 20I9: 154-160, with further literature).

The slow decline of greyware in Mazovian towns is accompanied by an equally slow increase of this group of wares in the hinterland. Interestingly, as in the case of 
traditional pottery, the spread of vessels fired in a reducing atmosphere begins in western Mazovia and reaches the north-eastern outskirts of the region the latest. Greyware vessels, mostly jugs, appear in the villages in the vicinity of Warsaw already in the Isth century. In the late 17 th century, their quantities reach $50 \%$ and then decline, mostly in favour of vessels fired in a highly oxidizing atmosphere (Morysiński 2005: table 4-9). The proportions of greyware vessels in the assemblages from the sixteenth-century petty gentry villages of eastern Mazovia are in the range of IO-20\%. The percentage of such ware group in the royal castle of Tykocin was only slightly higher. In the village of Leonowicze in Podlachia, greyware comprises up to $5 \%$ of the assemblages. In the majority of cases, greyware was represented mostly by tableware - jugs, pitchers, and plates. In the late 17 th and I8th centuries, the proportion of greyware, both kitchen and table vessels, in the assemblages from eastern Mazovia and Podlachia exceeds 50\% (Niegów) or even 60\% (Dubno, Białystok). It should be, however, mentioned here that the real mass spread of greyware in Podlachia started only at the turn of the i8th and 19th centuries, and their production is continued there up to the present time (Trzeciecki 2019: 159-160, with further literature).

Post-medieval Mazovian greyware vessels are highly differentiated in terms of their stylistic features. Among the most characteristic groups, highly decorated polished tableware, mostly jugs and pitchers, manufactured in the i6th and early i 7 th centuries, should be mentioned first. They were produced in the majority of Mazovian towns, among them vessels from Płock (Fig. 3:I-5) and Płońsk (Fig. 3:6-8) deserve particular attention, primarily due to their individual and creative stylistic inventions. In the I7th and I8th centuries, the forms of greyware vessels became standardized, repeating the stylistic features of the whiteware pots. Burnished decoration still distinguishes the greywares, although the motifs became simplified (Fig. 3:9-13).

Glazed vessels fired in a controlled, highly oxidising atmosphere and described as "red-" or "whiteware", regarding the type of clay, are among the pivotal indicators of the post-medieval period. Although both of the groups appear in the pottery assemblages from Mazovia, their detailed characteristics depart from the general picture of post-medieval pottery in the Polish lands. First and foremost, the surprisingly low percentage of glazed vessels deserves particular attention. Although the quantity of glazed ware in the assemblages from Warsaw ranges from $35-45 \%$ in the second half of the I6th century, up to $55-80 \%$ in the second half of the I8th century (Starski 2013: table 2, 3; Trzeciecki 20I7a: table 93, 94; 2020a; Smoliński and Trzeciecki 2020; Rudnicki and Trzeciecki 202I), data from the other Mazovian towns reveal a completely different picture. The percentage of glazed ware in Płock gradually increases from $3 \%$ in the second half of the I6th century, up to $7 \%$ in the second half of the I8th century (Trzeciecki 2016: table 3, 5, 39, 6I). Their quantity in Przasnysz (Czeladnicza St.) is equally low, from less than $1 \%$ in the 16 th century up to $5 \%$ in the 18 th century. In Ciechanów (Market Sq.), in the assemblages dated to the late 16 th and 17 th centuries, 

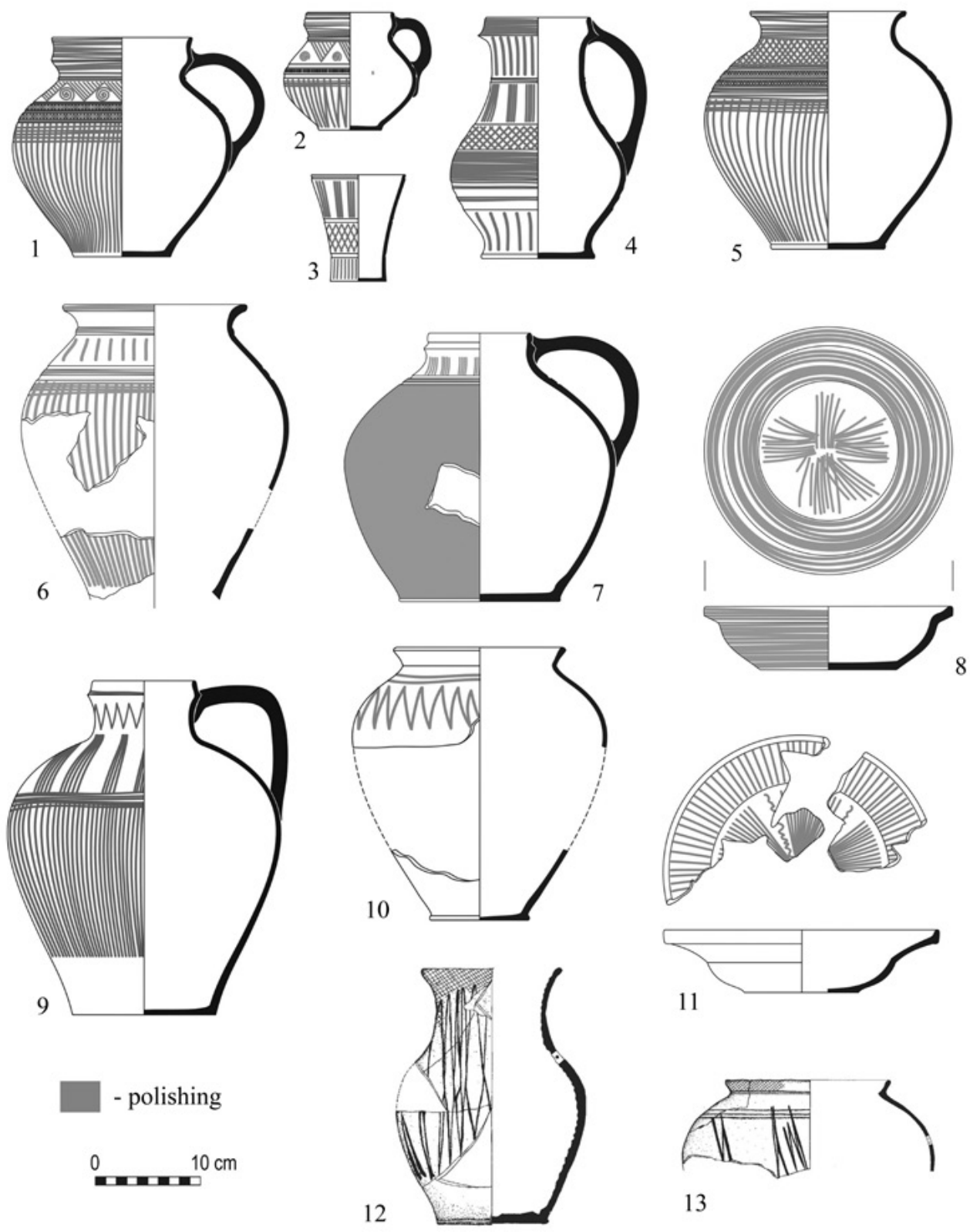

11

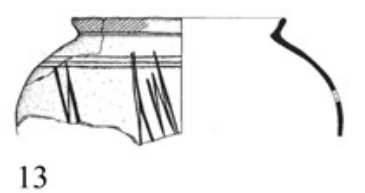

Fig. 3. Selection of greyware vessels with burnished decoration from the second half of the 16th century (1-7), mid-17th - mid-18th century (8-12): Płock (1-5, 9), Płońsk, Zduńska St. (6-8), Niegów (10, 11), Dubno (12, 13). 1-11 drawn by M. Trzeciecki, 12-13 after Garas and Karwowska 2013. 
glazed wares comprise only 9\%, while in Płońsk (Zduńska St.) their quantity reaches only 2\% (Smoliński et al., 2009; Smoliński and Trzeciecki 20ıо; Trzeciecki and Affelski 2016: 174).

Glazed vessels appeared in the rural hinterland of Warsaw already in the 16th century, with the proportion reaching $3 \%$. In the late 17 th century, they comprise about 50\% of the entire assemblage (Morysiński 2005: table 25-3I). In the sixteenthcentury villages of eastern Mazovia and Podlachia, glazed wares occur sporadically, as evidenced by the assemblages from Zambrzyce Stare and Leonowicze (Trzeciecki and Affelski 20I7: I82-I86; Gołembnik et al., 20I8: 337). Their percentage rises gradually from the mid-I7th century. In the assemblages from both the manor in Niegów and the palace in Dubno, it reaches 6\% (Garas and Karwowska 20I3: 234-235; Trzeciecki 20I7b, I72-174, Table I). Glazed red- and whiteware vessels comprise approximately I $4 \%$ of the pottery collection from the palace in Białystok, dated to the i8th century (Pawlata 20I3: 135-I36, table I).

The spread of white pottery (i.e., kitchen and table vessels manufactured of low ferrous clays and fired in highly oxidizing atmosphere) in Mazovia also has a specific character. Their proportions in the assemblages discussed here are, in general, low. The only exceptions, although each for different reasons, are Warsaw and Płock. In the latter, whiteware vessels were manufactured from the early i4th century up to the early I9th century, thanks to the easy access to the local sources of suitable clays. It is thus hardly surprising that in the mid-I6th century, the proportion of whiteware in Płock was equal to $21 \%$, while in the mid-18th century it reached 61\% (Trzeciecki 2016: table 3, 5). Interestingly, the Płock whiteware vessels appear to be extremely resistant to the stylistic changes taking place during the period in question - the S-shaped, unglazed, red-painted white pot, introduced in the early i4th century, remained the most common vessel type up to the end of the I8th century (Fig. 4:I-6).

Presumably, the majority of the whiteware pots found in the post-medieval Mazovian sites were manufactured in the pottery production centres located in the Holy Cross [Świętokrzyskie] Mountains region. Vessels produced there were distributed on a mass scale to the majority of towns in the middle Vistula basin since the early I6th century. Their formal stylistic features had a strong impact on locally produced grey- and redware pots (Bis 20I4: 53-64, with further literature).

Whiteware pots from the Holy Cross Mountains region appeared in Warsaw relatively early, at the end of the isth century. In the collections from the selected sites dated to the second half of the i6th century, their percentage reached $40 \%$ and increased to $60-80 \%$ at the end of the I8th century (Trzeciecki 2017a: table 93, 94; Smoliński and Trzeciecki 2020; Rudnicki and Trzeciecki 202I). The percentages of whiteware in the assemblages from other Mazovian towns are surprisingly low. In Ciechanów (Market Sq.), they comprise 3\% of the collection. Such values are even lower for the pottery assemblages from Przasnysz (Czeladnicza St., 0.9\%) and Płońsk 

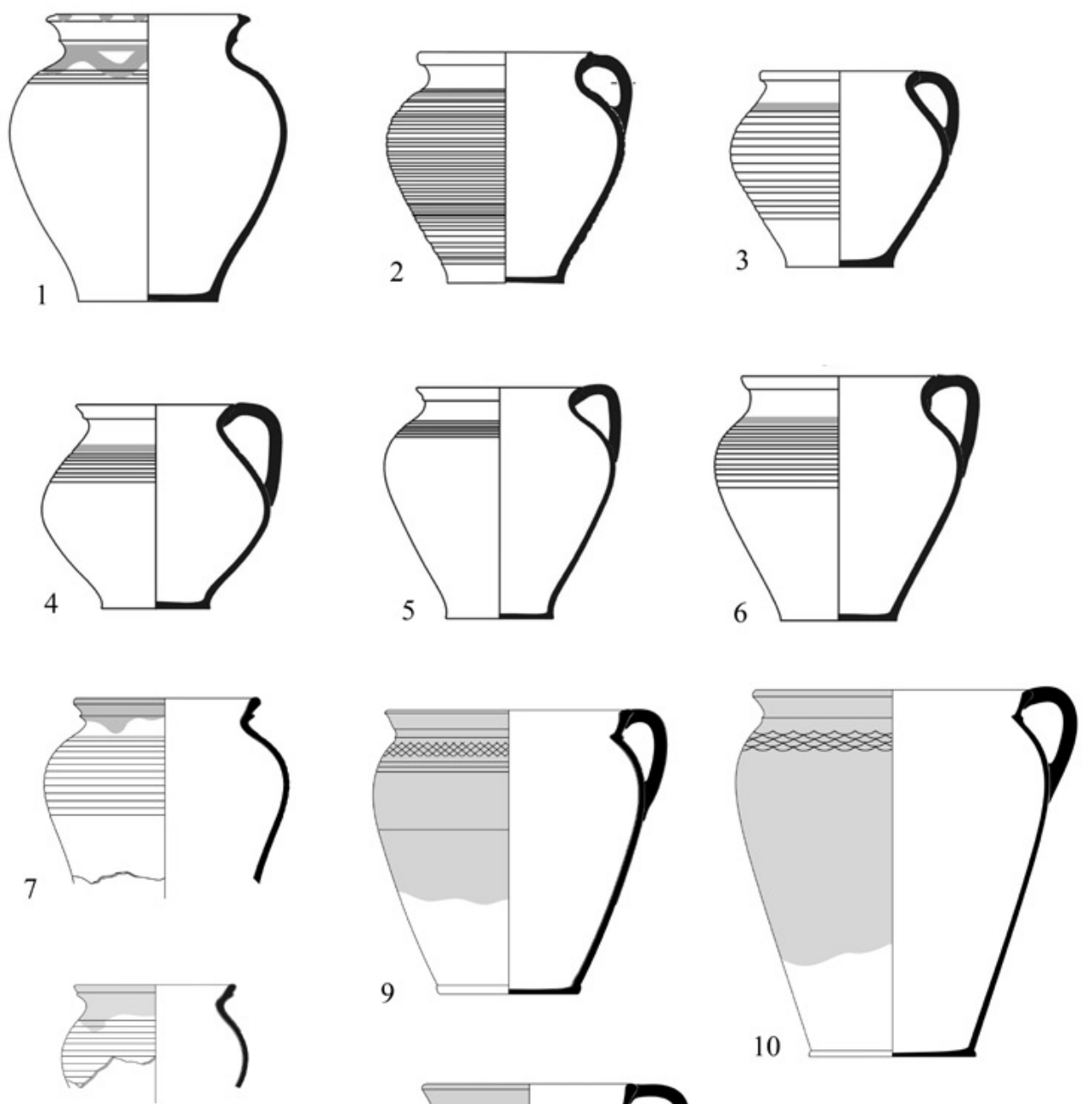

8
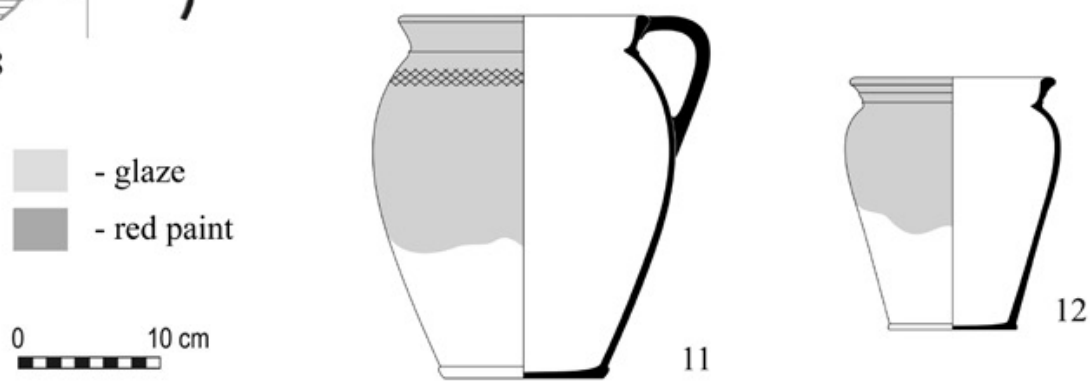

11

Fig. 4. Selection of whiteware vessels from the second half of the 16th century $(1-3,7,8)$, mid-17th to mid-18th centuries (4-6, 9-12): Płock (1-6), Warsaw, Castle Sq. (7-12). Drawn by M. Trzeciecki. 
(Zduńska St., 0.7\%). Although the discussed assemblages are dated to the I6th - midI7th centuries, we can assume that the increase of the whiteware in the following period was not significant - their percentage in the assemblages from Przasnysz (Czeladnicza St.), dated to the late I7th - early I8th centuries, reaches only 3\% (Smolinnski et al., 2009; Smoliński and Trzeciecki 2010; Trzeciecki and Affelski 2016: 174-176). Data on the assemblages from the Mazovian hinterland also indicate a relatively late inflow of whiteware. These vessels appeared in the second half of the I7th century, mostly in the villages located in the neighbourhood of Warsaw, in quantities of about $2-3 \%$. In the late i8th century, they comprise almost $80 \%$ of the assemblages (Morysiński 2005: table I2-I4). Percentages of whiteware vessels in the pottery collections from manors and palaces of eastern Mazovia and Podlachia in the late 17 th and I8th centuries are markedly low (Niegów - 4\%, Dubno - 6-8\%, Białystok - I2-I4\%; Garas and Karwowska 2013: 23I-234; Pawlata 20I3: 134-I35, Table I; Trzeciecki 20I7b: 17I).

Whiteware pots from both Warsaw and other Mazovian towns (with the exception of Płock) share the same stylistic features. Glazed, egg-shaped pots with the rims strongly drawn upwards, decorated by rouletting, often with a motif of so-called "fish scales", dominate the entire group (Fig. 4:9-I2). Such a stylistic pattern is widespread in the majority of towns receiving whiteware vessels imported from the Holy Cross Mountains region pottery-making centre in the late 17 th and $\mathrm{I} 8$ th centuries (see, e.g., Oniszczuk 2013: 85-88, for further literature).

The dissemination of vessels strongly associated with the changes in the table culture between the I6th and I9th centuries - slipware, faience, and porcelain - deserves particular attention (Fig. 5). It is noteworthy that faience and porcelain can hardly be found in the majority of pottery assemblages discussed here. Tableware of both porcelain and faience appears in eighteenth-century Warsaw, and comprises between 3 and I8\% of examined assemblages (Trzeciecki 202ob; see also Więcek 2012; 20I7; Klarecki 20I2). A relatively large collection of such vessels have been recovered in Tykocin (Bis and Bis 2013), smaller amounts of faience and porcelain occurred in the assemblages from palaces in Białystok (Pawlata 2013: 136-138) and Dubno (Garas and Karwowska 2013: 236-238).

On the contrary, glazed slipware (also known as "underglaze painted vessels") appear in the pottery assemblages from the majority of sites, excluding peasant villages. The question of their stylistic features and distribution is best represented by the finds from Warsaw (see: Meyza 1991; 1996; 2017, with further literature). Thus, it is sufficient only to mention that slipware appeared in Warsaw before the mid-I6th century, and its frequency grows in the following century, up to $20 \%$ of the average assemblage. In Płock, the first slipware plates are present in the pottery assemblages date to the second half of the I6th century (0.06\%). In late i8th century assemblages, their proportion rises to I.9\% (Trzeciecki 20I6: table 3, 4). The percentage of the slipware vessels is similar in seventeenth-century Ciechanów (Market Sq., I.5\%). In the other 

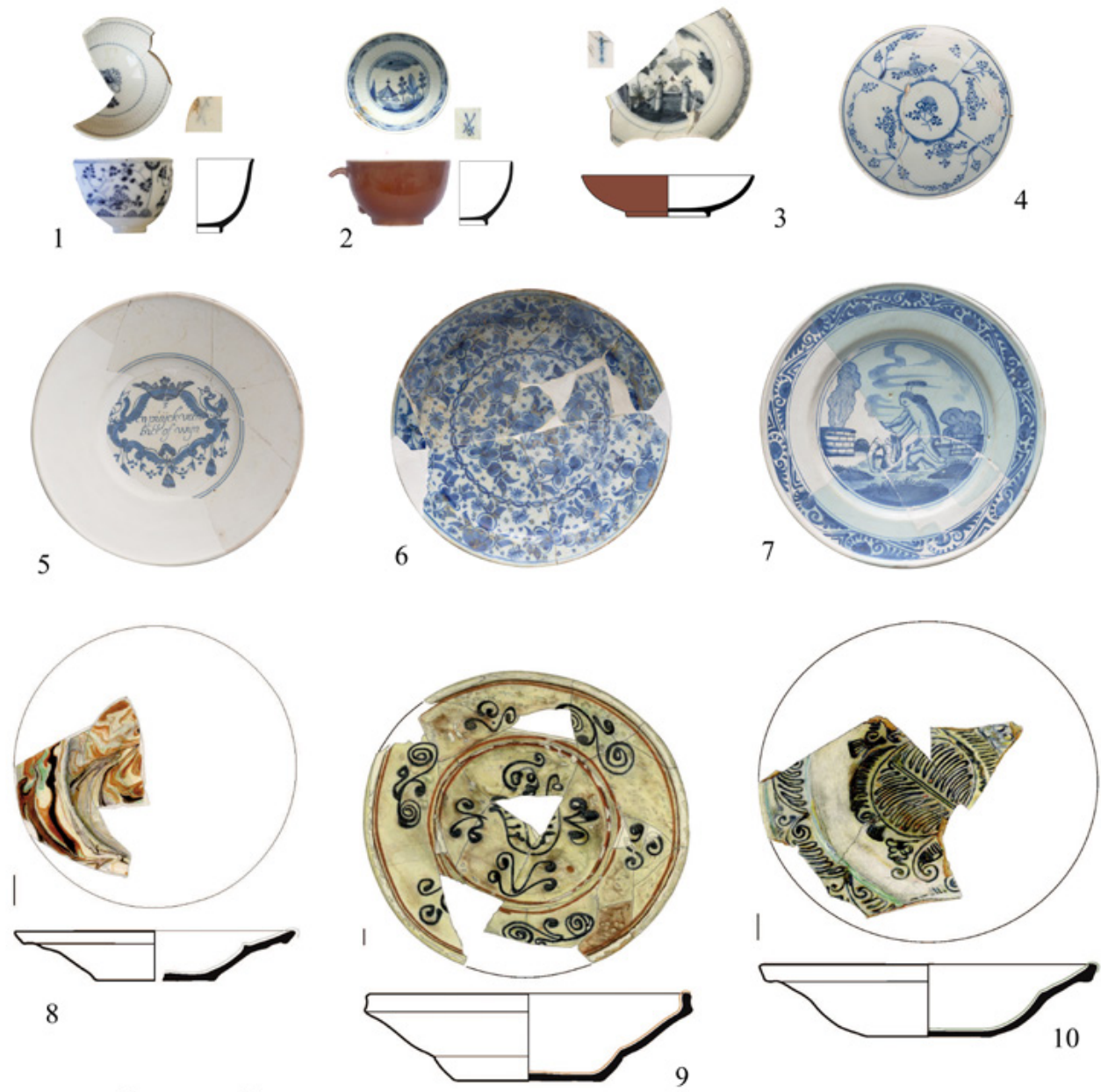

8

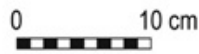

9

Fig. 5. Selection of eighteenth-century porcelain (1-4), faience (5-7), and slipware vessels (8-10) from Warsaw: Witosławski Palace (1-3), Castle Sq. (4-10). Photo: 1-3 - M. Trzeciecki, 4-7 after Więcek 2017, 8-10 after Meyza 2017.

towns mentioned here - Przasnysz (Czeladnicza St.) and Płońsk (Zduńska, St.) - the proportions do not even reach I\% (Smoliński et al., 2009; Smoliński and Trzeciecki 20IO; Trzeciecki and Affelski 20I6: 176). Equally low is the percentage of the slipware in the assemblage from Niegów (Trzeciecki 20I7b: 17I). Slightly more numerous sets of 
$44 \mid$ Maciej Trzeciecki

underglaze painted vessels were recovered from Dubno and Białystok, although their quantities do not exceed 4\% (Garas and Karwowska 20I3: 238-240; Pawlata 20I3: 136).

To sum up this brief review of the significant stylistic features of post-medieval pottery from Mazovia and Podlachia, both the traditional and innovative elements specific to the territory discussed here are worth considering again. The relatively long duration of early medieval pottery-making techniques, in the eastern part of the region continuing at least to the early I8th century, is an undoubtedly archaic feature. It is noteworthy that the manufacture of traditional ware appears to be strongly connected with the hinterland. The mass-scale production and use of greyware, the most typical feature of Mazovian post-medieval pottery, can hardly be regarded as traditional; vessels fired in the reducing atmosphere entered Mazovia already at the end of the Middle Ages. Their relatively high proportion in assemblages in the sixteenth-century Mazovian towns and their gradual spread into the hinterland can be regarded as a side effect of the late urbanization of the territory in question. It should be also emphasized here that sixteenth-century "urban" greyware vessels bear at least one feature typical of the post-medieval modes of manufacture, namely, the individual invention of artisans in adopting or creating new forms and decorative patterns (see Trzeciecki 20I6: 205-2II; 2019: 159-160, for further literature).

A negligible proportion of other fabric groups, considered as "type-fossils" of the post-medieval period, especially glazed red- and whiteware vessels, appears to be related to the widespread use of greyware. Glazed whiteware pots frequently occur only in Warsaw and its vicinity in the 17 th-18th centuries. Płock, with its own exceptionally conservative tradition of white kitchenware production, is a separate case. Undoubtedly, the stylistic features of the whiteware pots from the Holy Cross Mountains region had a very strong impact on the forms of grey-and redware vessels manufactured in Mazovia in the second half of the 17 th and the i8th centuries. The relatively small percentages of fine ware can be regarded as a sign of the strength of tradition. It seems, however, rather more probable that it documents the economic barriers limiting access to luxury goods to the narrow circle of the state's elites and the townspeople of Warsaw. It should be also stressed here that the low percentage of faience and porcelain is typical for the entire extent of the Polish lands, where larger eighteenth-century collections of fine ware occur only in a few of the biggest cities of the Polish-Lithuanian state, first and foremost in Gdańsk.

The remarks on post-medieval pottery from selected sites of Mazovia and Podlachia presented here raise questions about the interactions between the "old" and "new" in the pottery-making techniques and stylistic choices. The answers are not unambiguous. They rather highlight the multidimensionality of the past realities, the material traces of which are the vessel fragments that we excavate and study. 


\section{REFERENCES:}

Auch, M. and Trzeciecki, M. 20I5. Ceramika późnośredniowieczna i wczesnonowożytna. In M. Bis and W. Bis (eds), Tykocin - zamek nad Narwia (XV-XVIII w.). Badania archeologiczne w latach I96I-1963 i 1999-2007, I79-236. Warszawa.

Berg, M., Gottmann, F., Hodacs, H. and Nierstrasz, C. (eds) 2015. Goods from the East I600-180o. Basingstoke.

Bieńkowska, K. and Kiziukiewicz, N. 2006. Dziedzictwo archeologiczne Podlasia i Grodzieńszczyzny. Białystok.

Bis, M. 20I4. Późnośredniowieczne i wczesnonowożytne naczynia biate z Solca nad Wistą. Warszawa.

Bis, M. and Bis, W. 20I2. Badania archeologiczne z zakresu późnego średniowiecza i nowożytności na Mazowszu w latach 1989-2009. Kwartalnik Historii Kultury Materialnej 60(I): 133-I48.

Bis, M. and Bis, W. 2013. "Trzy puzdra z kaftiorami...” czyli o fajansie i porcelanie na tykocińskim zamku. Archaeologia Historica Polona 21: 257-295.

Cassidy-Geiger, M. (ed.). 2007. Fragile Diplomacy: Meissen porcelain for European courts ca. I7I0-63. New York.

Deetz, J. 1977. In small things forgotten: the archaeology of early American life. Garden City.

Gajewska, M. 1993. Garncarstwo nowożytne w Polsce. Stan i potrzeby badań. Prace i Materiaty Muzeum Archeologicznego i Etnograficznego w Łodzi 36: 159-169.

Garas, M. and Karwowska, H. 20I3. Naczynia ceramiczne. In H. Karwowska and A. Andrzejewski (eds), Założenie rezydencjonalne Sapiehów w Dubnie, 223-256. Białystok.

Gerritsen, A. 2016. From Long-Distance Trade to the Global Lives of Things: Writing the History of Early Modern Trade and Material Culture. Journal of Early Modern History 20: 526-544.

Gołembnik, A., Krasnodębski, D. and Trzeciecki, M. 20I8. Nowożytna wieś i ślady osadnictwa starożytnego na stanowisku 4 w Leonowiczach, gm. Michałowo. In A. Buko, D. Krasnodębski and W. Szymański (eds), Dawne osadnictwo Podlasia w świetle badan ratowniczych prowadzonych w latach 1996-200o na trasie gazociagu jamalskiego, 315-354. Warszawa.

Gierlach, O. 1966. Ceramika z wieków XVII i XVIII. Warszawskie Materiaty Archeologiczne I: II2-I40.

Janiszowski, K. I966. Ceramika XVI wieku. Warszawskie Materiaty Archeologiczne I: 50-III.

Kajzer, L. 1994. „Główne momenty” raz jeszcze. Uwagi o przemianach garncarstwa późnośredniowiecznego i nowożytnego w Polsce. In A. Gruszczyńska and A. Targońska (eds), Garncarstwo i kaflarstwo na ziemiach polskich od czasów średniowiecza do czasów wspótczesnych, I0-13. Rzeszów.

Kajzer, L. 1996. Wstęp do archeologii historycznej w Polsce. Łódź.

Klarecki, M. 20I2. Porcelanowe i fajansowe zabytki z XVIII wieku odnalezione podczas wykopalisk archeologicznych w ruinach dawnego Banku Polskiego. Warszawskie Materiaty Archeologiczne IO: IIO-II9.

Kruppé, J. 1967. Garncarstwo warszawskie w wiekach XIV i XV. Wrocław.

Lis, A. 20I7. Zasób źródeł archeologicznych dla studiów nad garncarstwem nowożytnym na Mazowszu. Kwartalnik Historii Kultury Materialnej 65(3): 343-352.

Majewski, T. and Schiffer, M. B. 2009. Beyond Consumption: Toward an Archaeology of Consumerism. In T. Majewski and D. Gaimster (eds), International Handbook of Historical Archaeology, I9I-208. New York.

Marcinkowski, M. 2009. Wytwórczość garncarska w Elblągu (na podstawie wybranego zbioru). Część 2 - okres nowożytny (XVI-XIX wiek). Pomorania Antiqua 22: I47-2I4. 
$46 \quad$ Maciej Trzeciecki

McCants, A. 2007. Exotic Goods, Popular Consumption, and the Standard of Living: Thinking about Globalization in the Early Modern World. Journal of World History I8(4): 433-462.

Meyza, K. 1991. Pseudomajolika znaleziona na terenie Starego Miasta i Zamku Królewskiego. Kronika Zamkowa 23(I): II8-I22.

Meyza, K. 1996. Ceramika zdobiona XVI-XVII wieku. Warszawa. Źródła archeologiczne do dziejów Zamku Królewskiego oraz Starej i Nowej Warszawy 2.

Meyza, K. 20I7. Ceramika zdobiona podszkliwnie. In Z. Polak and K. Meyza (eds), Między miastem i dworem. Badania archeologiczne placu Zamkowego w Warszawie w latach 1977-1983. Część 2, 7-23. Warszawa. Archeologia Dawnej Warszawy 4.

Morysiński, T. 2005. Nowożytne naczynia gliniane z Komorowa, Ruśca i Strzeniówki. Monument. Studia i Materiaty Krajowego Ośrodka Badań i Dokumentacji Zabytków 2: 375-4I4.

Musianowicz, K. 1975. Osady z wczesnego średniowiecza i średniowiecza w Brulinie-Koskach, pow. Ostrów Mazowiecka. Materiaty Starożytne i Wczesnośredniowieczne 3: 34I-386.

Oniszczuk, A. 20I3. Życie odbite w naczyniu. Konsumpcja luksusowa i codzienna w Gdańsku w XVII-XIX wieku na podstawie naczyń ceramicznych z terenu Centrum Dominikańskiego i kwartatu ulic Dtugi Targ - Powroźnicza. Warszawa.

Pawlata, L. 20I3. Archeologiczne badania wykopaliskowe na dziedzińcu kuchennym pałacu Branickich w Białymstoku. Podlaskie Zeszyty Archeologiczne 9: I2I-176.

Pela, W. 2013. Historia badan archeologicznych i architektonicznych dawnej Warszawy. Warszawa. Archeologia Dawnej Warszawy 2.

Starski, M. 20I3. Nowożytne naczynia ceramiczne z badań północnej pierzei placu Teatralnego w Warszawie. In W. Pela (ed.), Badania archeologiczno-architektoniczne pótnocnej pierzei placu Teatralnego $w$ Warszawie $w$ latach 1995-1997, 134-185. Warszawa. Archeologia Dawnej Warszawy 3.

Smoliński, A., Auch, M. and Trzeciecki, M. 2009. Opracowanie wyników ratowniczych badań wykopaliskowych wyprzedzajacych budowę kolektora sanitarnego wzdtuż ulicy Zduńskiej w Ptońsku, prowadzonych $w$ sezonie 2008. Unpublished typescript, Mazovian Voivodeship Heritage Office.

Smoliński, A. and Trzeciecki, M. 20I0. Sprawozdanie z nadzorów archeologicznych prowadzonych nad instalacją sieci c.o. w obrębie centrum Przasnysza. Unpublished typescript, Mazovian Voivodeship Heritage Office.

Smoliński, A. and Trzeciecki, M. 2020. Sprawozdanie z archeologicznych badań wykopaliskowych przeprowadzonych $w 2019$ r. na posesji Al. Solidarności 60B $w$ Warszawie. Unpublished typescript, Mazovian Voivodeship Heritage Office.

Świątkiewicz, P. 1992. Murowany dwór „na kopcu” w Gaju Nowym, gm. Góra św. Małgorzaty, województwo płockie. Prace i Materiaty Muzeum Archeologicznego i Etnograficznego w Łodzi 37-38: 265-302.

Świechowska, A. and Dukwicz, R. 1955. Warsztat garncarski z końca XVII w. In O. Puciata (ed.), Szkice Staromiejskie, I5I-173. Warszawa.

Trzeciecki, M. 2016. Ceramika ptocka między XI a XIX wiekiem. Studium archeologiczne. Warszawa.

Trzeciecki, M. 20I7a. Nowożytne naczynia kuchenne z badań na placu Zamkowym w Warszawie. In Z. Polak and K. Meyza (eds), Między miastem a dworem. Badania archeologiczne placu Zamkowego w Warszawie w latach 1977-1983. Częś́ I, 253-352. Warszawa. Archeologia Dawnej Warszawy 4.

Trzeciecki, M. 20I7b. Naczynia gliniane z XVII-XVIII wieku z badań zespołu podworskiego w Niegowie pod Wyszkowem. Przyczynek do poziomu życia szlacheckiej prowincji. Kwartalnik Historii Kultury Materialnej 65(2): 169-187. 
Trzeciecki, M. 2019. „Medieval” Greyware in Post-Medieval North-East Poland. Backwardness or Genius Loci. In G. Blažková and K. Matějková (eds), Post-medieval pottery between (its) borders, 153-166. Gloucester. Europa Postmediaevalis I.

Trzeciecki, M. 2020a. Sprawozdanie z archeologicznych badań wykopaliskowych przeprowadzonych $w$ latach 20I8-20I9 wokót patacu Branickich w Warszawie, ul. Miodowa 6. Unpublished typescript, Mazovian Voivodeship Heritage Office.

Trzeciecki, M. 2020b. "A Nice Cup of Tea”. Pottery as Material Evidence of Changes in the Table Culture of I8th-century Warsaw. In G. Blažková and K. Matějková (eds), Post-medieval pottery in the spare time, I09-I20. Prague. Europa Postmediaevalis 2.

Trzeciecki, M. and Affelski, J. 20I6. Relikty zabudowy bloku śródrynkowego Ciechanowa (XVI-XVIII w.). Raport NID II: I7I-I88.

Trzeciecki, M. and Affelski, J. 20I7. Osadnictwo wczesnośredniowieczne i z okresu nowożytnego na stanowisku nr 4 w Zambrzycach Starych, gm. Rutki, woj. podlaskie. Raport NID I2: 169-198.

Trzeciecki, M. and Rudnicki, M. 202I. Sprawozdanie z archeologicznych badań wykopaliskowych przeprowadzonych w 2019 r. na posesji przy ul. Dobrej 55 w Warszawie. Unpublished typescript, Mazovian Voivodeship Heritage Office.

Więcek, E. 20I2. Kuchnia i jadalnia zamożnych mieszkańców XVIII-wiecznej Warszawy. Warszawskie Materiaty Archeologiczne I0: 88-109.

Więcek, E. 20I7. Ceramika szlachetna. In Z. Polak and K. Meyza (eds), Między miastem i dworem. Badania archeologiczne placu Zamkowego $w$ Warszawie w latach 1977-1983. Częś́ 2, 25-44. Warszawa, Archeologia Dawnej Warszawy 4. 